\title{
Tribological studies of different bioimplant materials for orthopedic application using Taguchi experimental design
}

\author{
Sachin G. Solanke, Vivek R. Gaval \\ Department of General Engineering, Institute of Chemical Technology, Mumbai 400019 India \\ Corresponding author: Vivek R. Gaval (vr.gaval@ictmumbai.edu.in)
}

\begin{abstract}
In this research ball on disc wear tests have been carried out with ASTM G-99 standard at room temperature in simulated body fluid. The tribological property such as the coefficient of friction and wear weight loss was studied by using the Taguchi design of experiments. The design of the experiment was done using L8 orthogonal array to determine the collective contribution of the wear parameters. An analysis of variance demonstrated that the individual contribution of type of material factor was $97.15 \%$ and $66.66 \%$ for the coefficient of friction and wear weight loss respectively, which is the highest individual contribution as compared to other factors. It was concluded that the coefficient of friction and wear weight loss is mainly influenced by type of material factor. The analysis of the signal-to-noise ratio shows that the optimal coefficient of friction and wear weight loss was obtained with CoCrMo material at an applied normal load of $5 \mathrm{~N}$ with a sliding velocity of $0.05 \mathrm{~m} / \mathrm{s}$ for a track diameter of $30 \mathrm{~mm}$. To check the accuracy of results a confirmation test was carried out which indicates that predicted values are very close to the experimental values and the model is significant to predict the coefficient of friction. The results showed that the coefficient of friction and wear weight loss increases with increasing the applied load and sliding velocity. The microstructure of all substrates materials was analyzed using a scanning electron microscope. Wear track study showed that adhesive dominant wear mechanism for all four different substrate materials.
\end{abstract}

Keywords: Analysis of variance, Coefficient of friction, Pin on disc, Regression equation, Signal to noise ratio, Weight loss

\section{Introduction}

For improvement of research in the field of biomaterials engineering, it is necessary to study the tribological behavior of the material to improve the existing used biomaterials otherwise for the development of new virgin materials with exceptional properties [1]. Generally, the metal alloy has been used largely in the manufacturing of orthopedic implants. The highest quality and top superiority of orthopedic implants and instrumentation along with feasible cost are the demand of the 21st-century world. For safe and effective use of orthopedic implants that are left in vivo for a long period, it is necessary to study the tribology, mechanical and biological properties of orthopedic bio implant substrate materials. Implant materials subjected to sliding and rubbing contact action, the poor wear resistance material generates the wear debris which causes inflammation and pain at the joint. Wear is explained as the "loss of material in particulate form as a consequence of relative motion between two surfaces" [2]. Several factors contribute to the long-term survivorship in vivo of a biomedical implant. Out of this wear can be a major influencing factor for the proper performance of orthopedic bioimplant materials in an actual condition [3].
Bone and bone tissue suffer substantial loads during physical activity of the human body so it is mandatory to have a better load-bearing characteristic of artificial implants. Load-bearing orthopedic bioimplants material like knee and hip joints are made from stainless steels or titanium alloys because of their better corrosion and mechanical properties [4- 5]. Ti-based alloys an important bioimplant material that is generally used in total hip joint replacement. These alloys when compared with Co-28Cr6Mo exhibit more wear which is primarily due to abrasion and cracking [6]. For better durability in the human body, the superior wear mechanism and surface modification process was suggested for orthopedic implant material for long life and proper work functionality [7]. Generally, the modes of failure in engineering materials are corrosion failure, fatigue failure and wear failure, and wear failure is more prevailing in joint prostheses $[8,9,10]$. The tribological properties of material like wear rate, wear mechanism largely depends upon the manufacturing process of alloys. The heat treatment methods have more influence on the performance of bioimplant alloys [11]. So for the effectiveness of bioimplant material in the living body, it is necessary to study all aspects of bioimplant 


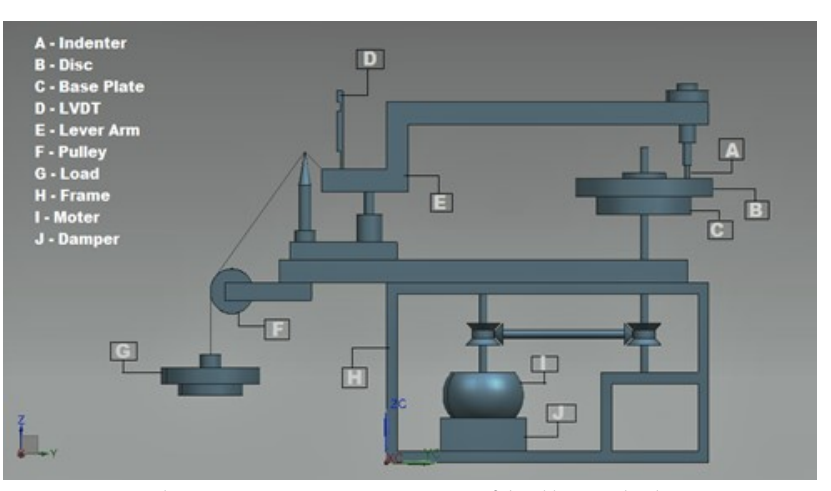

Figure 1. Schematic arrangement of ball on disk wear machine.

material. A high and considerable wear rate is a serious problem in the orthopedic implant. Wearing or surface rubbing between two parts leads to the production of wear debris and the metal ions are released and these ions contact with blood and tissues which causes the serious problem. So to avoid this it is required to impart superior properties to the material [12]. Experimentation output is very important to validate and evaluate any process. The design of experiment of the Taguchi method is the plan and analyzed the results of experiments [13]. Sachin et al. implemented a Taguchi-simulated annealing approach to examine the wear behavior of biomedical implant material such as silicon nitride. This approach was successfully used to predict the optimal combination of input factors [14]. Babu et al. focuses on the tribological properties of Ti3Al-2.5V titanium alloy by using the Taguchi method. Results revealed that the optimum process parameters were found by the Taguchi method using the regression equation [15].

In the reported data there is no information available about COF, wear weight loss values under wet conditions as per the process parameters given in table 2. The selection of wear parameters was based on the similar conditions of wear to which the femoral ball head is subjected inside the acetabular cup. Generally, during walking the stress produced in a hip prosthesis is in the range of 0.7 to $4 \mathrm{MPa}[16,17]$. Metallic hip prosthesis is expected to sustain frictional forces for a minimum of 18 to 25 years [18]. Since it is not feasible to carry out wear studies for a period of 18 to 25 years, the high value of applied normal load in the order of $10 \mathrm{~N}$ is maintained during wear testing. For determining the average wear weight loss of bioimplant metallic samples, three repeat experiments were carried out and average values of three measurements was consider. Also from the literature, it has been noticed that no detailed findings are available on tribological behavior of different bioimplant materials by using the statistical approach. So in this research wear behavior of different bioimplant substrates materials investigated with the help of Taguchi design of experiment. The major aim of this study is to select and introduced the suitable material for an orthopedic loadbearing implant and investigate and analyzed the effect of input parameters on the tribological properties of materials.

\section{Materials and method}

\subsection{Schematic arrangement of ball on disk machine.}

Ball on disk wear machine (DUCOM, Bangalore, India) are used to determine the wear of materials during sliding contact. The flat disk is rotated against the stationary ball at a specified load. The wear between the specimen and ball was noted by the linear variable differential transformer sensor which was mounted on the machine. Wear ball on disk machine connected with a computer (ACER VERITON M200-H81 DESKTOP, PCI-E -6321 NI Card, DUCOM, Bangalore, India). The PC is loaded with WINDUCOM 2010 software for displaying the results in graphical form. The schematic arrangement of ball on disk wear machine is shown in figure 1.

\subsection{Taguchi design of experiments for wear test}

In this study wear ball on disk machine was used to study the COF and weight loss of different substrate materials. Specimen of $40 \mathrm{~mm}$ diameter and $6 \mathrm{~mm}$ thickness (Substrate material) were polished to a roughness value of 0.1 to $0.5 \mu \mathrm{m}$. A steel ball (indenter) of $8 \mathrm{~mm}$ diameter was used. The substrate materials were tested under wet conditions at different applied normal load $(\mathrm{P})$, sliding velocity (V) and track diameter (TD) as per the ASTM G-99 standard. For wet condition, the specimen was immersed in SBF using the same test condition. The SBF is prepared using Kokubo's recipe. This solution contains various ions and have a common $\mathrm{pH}$ of 7.25 similar to human plasma $[19,20]$. The chemical composition as presented below in table 1 .

Table 1. Chemical ingredients of SBF

\begin{tabular}{cc} 
Ingredient of SBF & Amount $(\mathbf{g} / \mathbf{l})$ \\
\hline $\mathrm{NaCl}$ & 7.995 \\
$\mathrm{NaHCO}_{3}$ & 0.351 \\
$\mathrm{KCl}$ & 0.223 \\
$\mathrm{~K}_{2} \mathrm{HPO}_{4} \cdot 3 \mathrm{H} 2 \mathrm{O}$ & 0.229 \\
$\mathrm{MgCl}_{2} \cdot 6 \mathrm{H} 2 \mathrm{O}$ & 0.304 \\
$\mathrm{CaCl}_{2}$ & 0.279 \\
$\mathrm{Na}_{2} \mathrm{SO}_{4}$ & 0.072 \\
$\left(\mathrm{CH}_{2} \mathrm{OH}\right)_{3} \mathrm{CNH}$ & 6.056 \\
$1 \mathrm{kmol} / \mathrm{m}^{3} \mathrm{HCI}$ & Adjust the $\mathrm{pH}-7.25$ \\
Ultrapure water & Volume up to 1 litre \\
\hline
\end{tabular}

The wear tests were carried out by taking the Taguchi design of experiments to accomplish the objective of the experimental study. Mixed level type of design was used. In this study, four different parameters were used as the input source. Taguchi OA L8 was used, Generally OA reduced the number of experiments and increase the precision of experiments. Taguchi analysis was carried out with open source software Minitab 17. The influence of 
Table 2. Taguchi design factors

\begin{tabular}{lccc} 
Name of factor & Level values & Column & level \\
\hline Type of material & SS316L,CoCrMo, TIGR2, TIGR5 & 1 & 4 \\
Load (P) in N & 5,10 & 2 & 2 \\
Velocity (V) in m/s & $0.05,0.1$ & 3 & 2 \\
Track diameter (TD) in mm & 20,30 & 4 & 2 \\
\hline
\end{tabular}

Table 3. L8 OA used in Taguchi method

\begin{tabular}{ccccc} 
Experiment No. & Column 1 & Column 2 & Column 3 & Column 4 \\
\cline { 2 - 5 } 1 & Type of material & Load (P) & Velocity (V) & Track diameter (TD) \\
2 & SS316L & 5 & 0.05 & 20 \\
3 & SS316L & 10 & 0.1 & 30 \\
4 & CoCrMo & 5 & 0.05 & 30 \\
5 & CoCrMo & 10 & 0.1 & 20 \\
6 & TIGR2 & 5 & 0.1 & 20 \\
7 & TIGR2 & 10 & 0.05 & 30 \\
8 & TIGR5 & 5 & 0.1 & 30 \\
& TIGR5 & 10 & 0.05 & 20
\end{tabular}

Table 4. Design layout matrix and experimental results.

\begin{tabular}{|c|c|c|c|c|c|c|c|c|}
\hline $\begin{array}{l}\text { Experimental } \\
\text { No. }\end{array}$ & $\begin{array}{l}\text { Type of } \\
\text { material }\end{array}$ & $\begin{array}{l}\text { Load } \\
(\mathrm{P})\end{array}$ & $\begin{array}{l}\text { Velocity } \\
\text { (V) }\end{array}$ & $\begin{array}{c}\text { Track } \\
\text { diameter } \\
\text { (TD) }\end{array}$ & $\mathrm{COF}$ & $\begin{array}{l}\text { S/N ratio } \\
(\mathrm{dB})\end{array}$ & $\begin{array}{c}\text { Weight loss } \\
\text { in gram }\end{array}$ & $\begin{array}{l}S / N \\
\text { ratio } \\
(\mathrm{dB})\end{array}$ \\
\hline 1 & SS316L & 5 & 0.05 & 20 & 0.59 & 4.5829 & 0.00170 & 55.391 \\
\hline 2 & SS316L & 10 & 0.1 & 30 & 0.62 & 4.1521 & 0.00340 & 49.370 \\
\hline 3 & CoCrMo & 5 & 0.05 & 30 & 0.37 & 8.6359 & 0.00021 & 73.555 \\
\hline 4 & CoCrMo & 10 & 0.1 & 20 & 0.40 & 7.9588 & 0.00060 & 64.436 \\
\hline 5 & TIGR2 & 5 & 0.1 & 20 & 0.48 & 6.3751 & 0.00310 & 50.172 \\
\hline 6 & TIGR2 & 10 & 0.05 & 30 & 0.51 & 5.8485 & 0.00670 & 43.478 \\
\hline 7 & TIGR5 & 5 & 0.1 & 30 & 0.43 & 7.3306 & 0.00280 & 51.056 \\
\hline 8 & TIGR5 & 10 & 0.05 & 20 & 0.45 & 6.9357 & 0.00540 & 45.352 \\
\hline
\end{tabular}

each input parameter on the COF and weight loss was analyzed using ANOVA and $\mathrm{S} / \mathrm{N}$ ratio. Taguchi design factors are shown in the table 2.

The wear test was performed using the four parameters or factors such as type of material, applied normal load, sliding velocity, and track diameter. According to the rule that degree of freedom for an OA should be greater than or equal to the sum of those wear parameters, an L8 OA which has 8 rows and 4 columns were selected, L8 OA used in Taguchi method as shown in table 3.

The obtained COF and weight loss values were transformed into $\mathrm{S} / \mathrm{N}$ ratios for measuring the quality characteristics using Minitab 17 software. The $\mathrm{S} / \mathrm{N}$ ratio for COF and weight loss using 'smaller the better' characteristics. The significance of the controllable factor is investigated using the $\mathrm{S} / \mathrm{N}$ ratio approach which can be calculated as logarithmic transformation of the loss function is given as

$$
\mathrm{S} / \mathrm{N}=-10 \times \log \left(\frac{\sum \mathrm{Y}^{2}}{n}\right)
$$

Where $\mathrm{Y}$ is the observed data (COF and weight loss) and $\mathrm{n}$ is the number of observations or experiments. Irrespective of the category of the performance characteristic, the higher value of $\mathrm{S} / \mathrm{N}$ ratio corresponds to better performance [21]. The maximization of $\mathrm{S} / \mathrm{N}$ ratio signifies minimization of $\mathrm{COF}$ and weight loss. Observation of the response table of the $\mathrm{S} / \mathrm{N}$ ratio gives an optimal combination of input parameters for the required output characteristic.

\section{Result and discussion}

Before start and end of every test, the weight of substrate materials was noted by Electronic Weighing machine (Contech Instruments Ltd., Navi Mumbai, India). Value of COF is obtained from the data recorded in the form of excel sheet from the WINDUCOM 2010 machine software. The experiments were conducted and the average values are taken into consideration. The average value of $\mathrm{COF}$ and weight loss was shown in table 4 . From table 4 it observed maximum $\mathrm{S} / \mathrm{N}$ ratio of $8.6359 \mathrm{~dB}$ with minimum $0.37 \mathrm{COF}$ and a maximum $\mathrm{S} / \mathrm{N}$ ratio of 73.555 $\mathrm{dB}$ with a minimum $0.00021 \mathrm{gm}$ weight loss.

\subsection{Analysis of Variance (ANOVA)}

The experimental results were analyzed with ANOVA, which is used to investigate the influence of the considered wear parameters, namely, type of material, applied normal load, sliding velocity and sliding distance that significantly affects the performance measures. This analysis is carried 

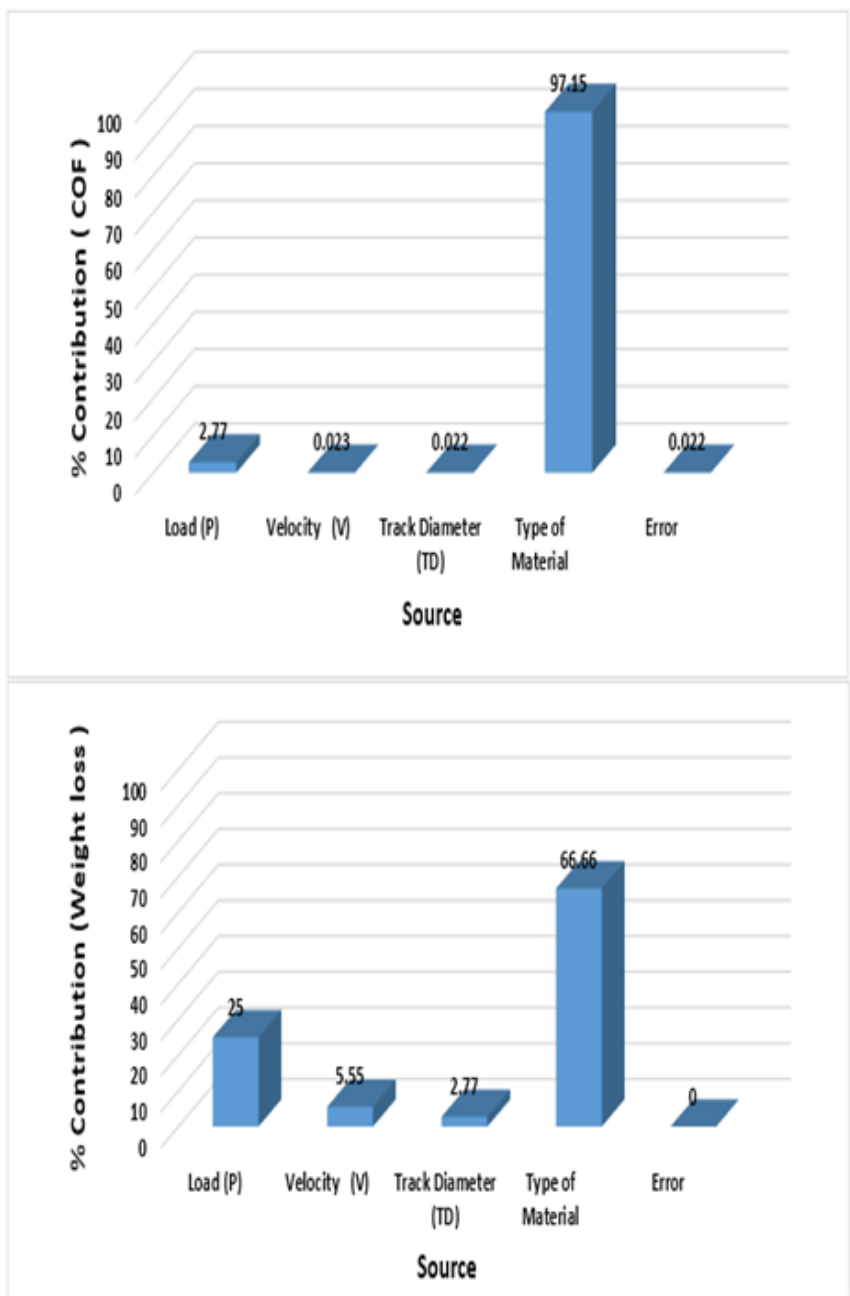

Figure 2. Percentage contribution of input variables on COF and wear weight loss

out for a significance of level $a=0.05$, i.e. for a confidence level of $95 \%$. Sources with a P-Value less than 0.05 were considered to have a statistically significant contribution to the performance measures.

From table 5, it can be observed that the percentage contributions of input source applied normal load, sliding velocity, track diameter and type of material to COF were $2.77 \%, 0.023 \%, 0.022 \%$ and, $97.15 \%$ respectively. Based on this ANOVA data for COF, the most important input parameter influencing the $\mathrm{COF}$ was the type of material factor. The type of material was the most significant

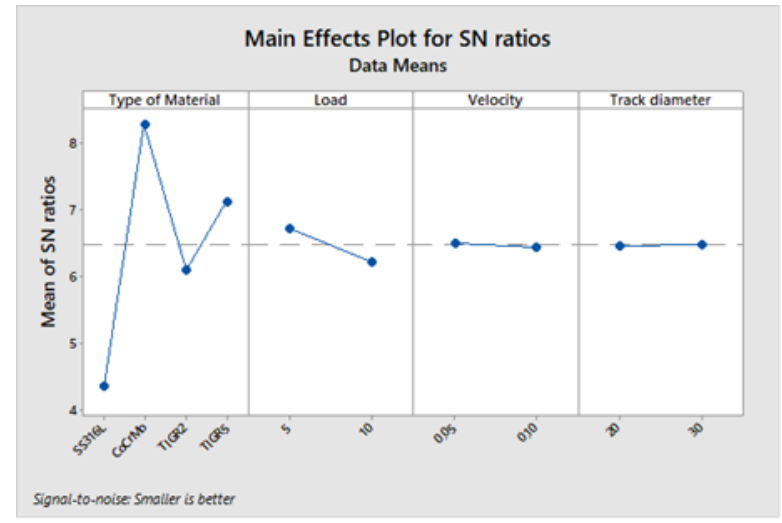

Figure 3. Main effect plot for $\mathrm{S} / \mathrm{N}$ ratio- $\mathrm{COF}$

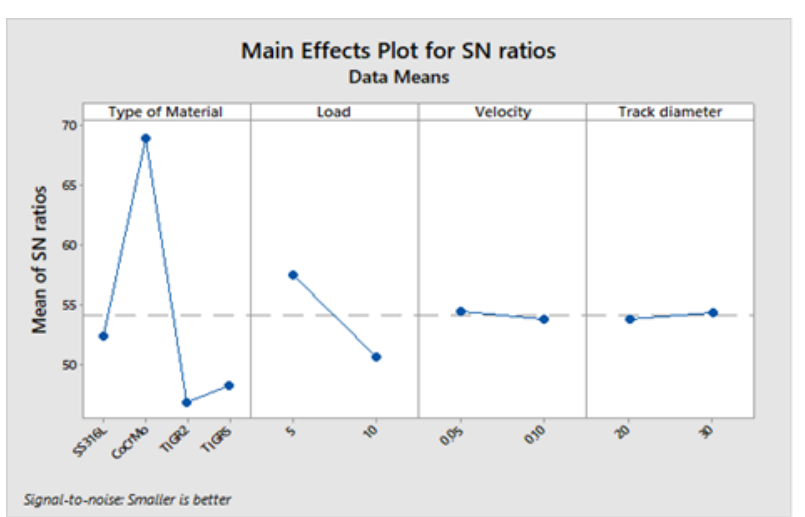

Figure 4. Main effect plot for S/N ratio- Wear weight loss

parameter having the highest statistical influence. The error rate was $0.022 \%$, it was considerably low. The statistical analysis is good and reliable when the error level should be less than $20 \%$ [22]. The corresponding P-Values for COF were $0.058,0.500,0.500$ and 0.020 for an applied normal load, sliding velocity, track diameter and type of material respectively. P-Values are more than 0.05 for input factors like applied normal load, sliding velocity and track diameter except for the type of material factor at the $95 \%$ confidence level. The P-Value in case of type of material is 0.020 which indicates a type of material is a significant factor for COF. Percentage contribution signifies individual contribution of a factor on the mean response. It is calculated by the following equation.

$$
\% \text { Contribution }=\frac{\text { Seq SS factor }}{\text { Seq SS total }} \times 100
$$

Form table 6 it was observed the most important input

Table 5. ANOVA for $\mathrm{S} / \mathrm{N}$ ratios- $\mathrm{COF}$

\begin{tabular}{cccccccc}
\hline Source & DF & Seq SS & Adj SS & Adj MS & F-Value & P-Value & Contribution (\%) \\
Load (P) & 1 & 0.001513 & 0.001513 & 0.001513 & 121 & 0.058 & 2.77 \\
Velocity (V) & 1 & 0.000013 & 0.000013 & 0.000013 & 1.00 & 0.500 & 0.023 \\
Track diameter (TD) & 1 & 0.000012 & 0.000012 & 0.000012 & 1.00 & 0.500 & 0.022 \\
Type of material & 3 & 0.052937 & 0.052937 & 0.017646 & 1411.67 & 0.020 & 97.15 \\
Error & 1 & 0.000012 & 0.000012 & 0.000012 & & & 0.022 \\
Total & 7 & 0.054487 & 0.054487 & & & & 100 \\
\hline
\end{tabular}


Table 6. ANOVA for S/N ratios- Wear weight loss

$\begin{array}{cccccccc}\text { Source } & \text { DF } & \text { Seq SS } & \text { Adj SS } & \text { Adj MS } & \text { F-Value } & \text { P-Value } & \text { Contribution }(\%) \\ \text { Load (P) } & 1 & 0.000009 & 0.000009 & 0.000009 & 715.13 & 0.024 & 25.00 \\ \text { Velocity (V) } & 1 & 0.000002 & 0.000002 & 0.000002 & 175.78 & 0.048 & 5.55 \\ \text { Track diameter (TD) } & 1 & 0.000001 & 0.000001 & 0.000001 & 55.53 & 0.085 & 2.77 \\ \text { Type of material } & 3 & 0.000024 & 0.000024 & 0.000008 & 652.43 & 0.029 & 66.66 \\ \text { Error } & 1 & 0.000000 & 0.000000 & 0.000000 & & & 0.00 \\ \text { Total } & 7 & 0.000036 & 0.000036 & & & & 100\end{array}$

Table 7. Response table for S/N ratio- COF

\begin{tabular}{lllll}
\hline Level & $\begin{array}{l}\text { Type of } \\
\text { material }\end{array}$ & $\begin{array}{l}\text { Load } \\
(\mathrm{P})\end{array}$ & $\begin{array}{l}\text { Velocity } \\
(\mathrm{V})\end{array}$ & $\begin{array}{l}\text { Track } \\
\text { diameter } \\
(\mathrm{TD})\end{array}$ \\
1 & 4.368 & 6.731 & 6.501 & 6.463 \\
2 & 8.297 & 6.224 & 6.454 & 6.492 \\
3 & 6.112 & & & \\
4 & 7.133 & & & \\
Delta & 3.93 & 0.507 & 0.047 & 0.029 \\
Rank & 1 & 2 & 3 & 4 \\
\hline
\end{tabular}

Table 8. Response table for S/N ratio- Weight loss

\begin{tabular}{ccccc}
\hline Level & $\begin{array}{c}\text { Type of } \\
\text { material }\end{array}$ & $\begin{array}{c}\text { Load } \\
(\mathrm{P})\end{array}$ & $\begin{array}{c}\text { Velocity } \\
(\mathrm{V})\end{array}$ & $\begin{array}{c}\text { Track } \\
\text { diameter } \\
(\mathrm{TD})\end{array}$ \\
1 & 52.38 & $\mathbf{5 7 . 5 4}$ & $\mathbf{5 4 . 4 4}$ & 53.84 \\
2 & $\mathbf{6 9 . 0 0}$ & 50.66 & 53.76 & $\mathbf{5 4 . 3 7}$ \\
3 & 46.83 & & & \\
4 & 48.20 & & & \\
Delta & 22.17 & 6.88 & 0.69 & 0.53 \\
Rank & 1 & 2 & 3 & 4 \\
\hline
\end{tabular}

Table 9. Optimal values for $\mathrm{COF}$ and weight loss from response table for $\mathrm{S} / \mathrm{N}$ ratios

\begin{tabular}{|c|c|c|c|c|c|}
\hline \multicolumn{3}{|c|}{ Optimal values for COF from response table for $\mathrm{S} / \mathrm{N}$ ratios } & \multicolumn{3}{|c|}{ Optimal values for weight loss from response table for $\mathrm{S} / \mathrm{N}$ ratios } \\
\hline Input Factor & Level & $\mathrm{S} / \mathrm{N}$ ratio $(\mathrm{dB})$ & Input Factor & Level & $\mathrm{S} / \mathrm{N}$ ratio $(\mathrm{dB})$ \\
\hline Type of material & 2 & 8.297 & Type of material & 2 & 69.00 \\
\hline Load $(\mathrm{P})$ & 1 & 6.731 & Load $(\mathrm{P})$ & 1 & 57.44 \\
\hline Velocity (V) & 1 & 6.501 & Velocity (V) & 1 & 54.44 \\
\hline Track diameter (TD) & 2 & 6.492 & Track diameter (TD) & 2 & 54.37 \\
\hline
\end{tabular}

source influencing the wear weight loss was the type of material factor which has a $66.66 \%$ contribution as compared to other factors. The corresponding P-Values for weight loss were $0.024,0.048,0.085$ and 0.029 for an applied normal load, sliding velocity, track diameter and type of material respectively. The P-Value in case of applied normal load and sliding velocity less than 0.05 as like type of material factor which indicates these input parameters also have a statistically significant contribution to the performance measures in case of weight loss. The percentage contributions of input variables that is wear

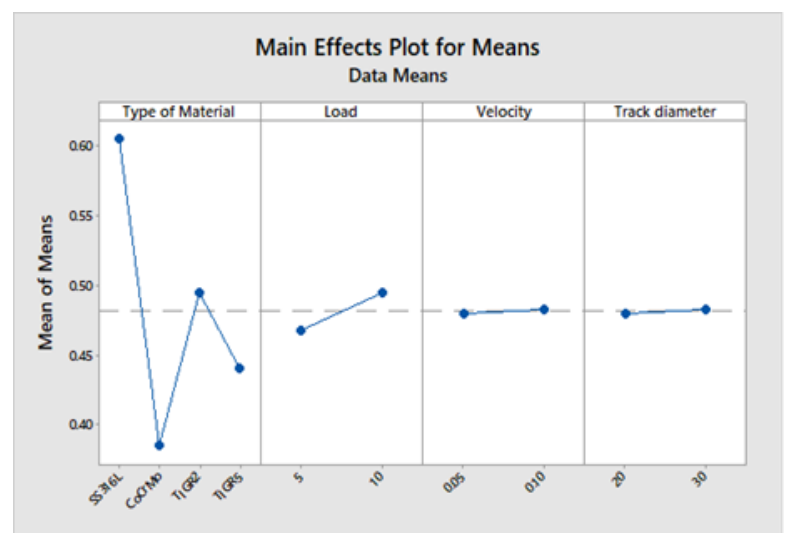

Figure 5. Main effect plot for Means- COF parameters on the COF and wear weight loss are shown in figure 2 .

\subsection{Main effects plot and response table for $\mathrm{S} / \mathrm{N}$ ratio of the COF and weight loss}

The main plot for $S / N$ ratios for the $C O F$ and weight loss is shown in figure 3 and figure 4 . From both plots, the highest value for each input parameter in the $\mathrm{S} / \mathrm{N}$ ratio obtained through the Taguchi method gives the optimal value of that input parameter [23]. It can be observed from both figure that the optimal input parameters for $\mathrm{COF}$ and

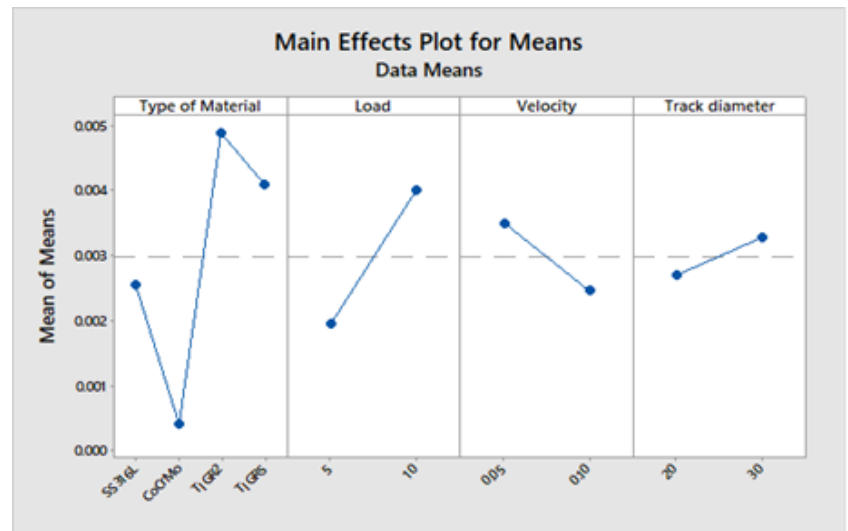

Figure 6. Main effect plot for Means- Wear weight loss 
weight loss during the wear testing are CoCrMo as type of material, applied normal load is $5 \mathrm{~N}$, sliding velocity is 0.05 $\mathrm{m} / \mathrm{s}$ and the track diameter is $30 \mathrm{~mm}$. Response table for $\mathrm{S} / \mathrm{N}$ ratio for the smaller is better characteristic in the Taguchi method for COF and wear weight loss is shown in table 7 and table 8 below.

The response table for $S / N$ ratios for $C O F$ shows the optimal value of input factors for the lowest COF. From the response table, it was observed that for type of material, the level was 2 with $\mathrm{S} / \mathrm{N} 8.297 \mathrm{~dB}$, for the applied normal load, the level was 1 with $S / N$ ratio $6.731 \mathrm{~dB}$, for the sliding velocity the level was 1 with $\mathrm{S} / \mathrm{N}$ ratio $6.501 \mathrm{~dB}$ and for track diameter the level was 2 with $S / N$ ratio $6.492 \mathrm{~dB}$. The bolded values in table 7 and 8 show the optimal input factors for obtaining the lowest COF and weight loss. The corresponding optimum values for wear weight loss concerning $\mathrm{S} / \mathrm{N}$ ratio values obtained from the response table is shown in the table 9.

Response table for means for the COF and weight loss for the smaller is better characteristic shown in table 10 and 11.

Table 10. Response table for means- COF

\begin{tabular}{ccccc}
\hline Level & $\begin{array}{c}\text { Type of } \\
\text { material }\end{array}$ & $\begin{array}{c}\text { Load } \\
(\mathrm{P})\end{array}$ & $\begin{array}{c}\text { Velocity } \\
(\mathrm{V})\end{array}$ & $\begin{array}{c}\text { Track } \\
\text { diameter (TD) }\end{array}$ \\
1 & 0.6050 & 0.4675 & 0.4800 & 0.4800 \\
2 & 0.3852 & 0.4950 & 0.4825 & 0.4825 \\
3 & 0.4950 & & & \\
4 & 0.4400 & & & \\
Delta & 0.22 & 0.0275 & 0.0025 & 0.0025 \\
Rank & 1 & 2 & 3.5 & 3.5 \\
\hline
\end{tabular}

Table 11. Response table for means- Wear weight loss

\begin{tabular}{ccccc}
\hline Level & $\begin{array}{c}\text { Type of } \\
\text { material }\end{array}$ & Load $(\mathrm{P})$ & $\begin{array}{c}\text { Velocity } \\
(\mathrm{V})\end{array}$ & $\begin{array}{c}\text { Track } \\
\text { diameter } \\
(\mathrm{TD})\end{array}$ \\
1 & 0.002550 & 0.001952 & 0.003503 & 0.002700 \\
2 & 0.000405 & 0.004025 & 0.002475 & 0.003278 \\
3 & 0.004900 & & & \\
4 & 0.004100 & & & \\
Delta & 0.004495 & 0.002073 & 0.001027 & 0.000577 \\
Rank & 1 & 2 & 3 & 4 \\
\hline
\end{tabular}

Mean COF and weight loss values are shown in the main effects plot in figure 5 and figure 6 . It can be observed that COF and weight loss increases as the applied normal load increases in a linear trend. The COF and weight loss of any substrates material increases with an increase in the load. Considering the input variables like sliding velocity and track diameter from figure 5, it was observed that both input parameter having a similar significant effect on the COF. From figure 5 and obtained P-Values in table 5 which indicates these two input factors influence the COF very weakly. Whereas from figure 6 and obtained P-Values in table 6 , the weight loss was strongly influenced by the applied normal load, sliding velocity and type of material input factors. It can be noted that the COF is lowest when using the CoCrMo material and highest when using the SS316Lmaterial. Low COF and weight loss obtained when using the CoCrMo material could be attributed to its good tribological properties. It was observed that the COF and weight loss values for the CoCrMo material are $0.37,0.40$ and $0.00021 \mathrm{gm}, 0.0006 \mathrm{gm}$ respectively for mentioned input process parameters in table 4 .

\subsection{Regression equation and Model summary}

The regression equation for the desired output was obtained with the help of statistical software Minitab 17. The relationship between the COF and the input variables were modelled for different substrate materials used in the experiments. The different regression equation for the COF as follows:

Table 12. Regression equation- COF

$\begin{array}{ll}\begin{array}{l}\text { Type of } \\ \text { material }\end{array} & \\ \text { SS316L } & \text { COF }=0.55375+0.005500 \text { Load } \\ & +0.0500 \text { Velocity }+0.000250 \mathrm{TD} \\ \text { CoCrMo } & \text { COF }=0.33375+0.005500 \text { Load } \\ & +0.0500 \text { Velocity }+0.000250 \mathrm{TD} \\ \text { TIGR2 } & \text { COF }=0.44375+0.005500 \text { Load } \\ & +0.0500 \text { Velocity }+0.000250 \mathrm{TD} \\ \text { TIGR5 } & \text { COF }=0.38875+0.005500 \text { Load } \\ & +0.0500 \text { Velocity }+0.000250 \mathrm{TD}\end{array}$

Same as the relationship between the weight loss and the input variables were modelled for different substrate materials used in the experiments. The different regression equation for the weight loss as follows:

Table 13. Regression equation- Weight loss

\begin{tabular}{|c|c|}
\hline $\begin{array}{l}\text { Type of } \\
\text { material }\end{array}$ & \\
\hline SS316L & $\begin{array}{l}\text { Weight loss }=-0.000461+0.000415 \text { Load } \\
-0.02055 \text { Velocity }+0.000058 \mathrm{TD}\end{array}$ \\
\hline CoCrMo & $\begin{array}{l}\text { Weight loss }=-0.002606+0.000415 \text { Load } \\
-0.02055 \text { Velocity }+0.000058 \mathrm{TD}\end{array}$ \\
\hline TIGR2 & $\begin{array}{l}\text { Weight loss }=0.001889+0.000415 \text { Load } \\
-0.02055 \text { Velocity }+0.000058 \text { TD }\end{array}$ \\
\hline TIGR5 & $\begin{array}{l}\text { Weight loss }=0.001089+0.000415 \text { Load } \\
-0.02055 \text { Velocity }+0.000058 \text { TD }\end{array}$ \\
\hline
\end{tabular}

From the model summery in table 14 and 15, it observe that the value of R-sq is $99.98 \%$ for COF and $99.97 \%$ for weight loss which indicates this model can be considered for predicting the optimal process parameter combination.

\subsection{Verification experiment}

A confirmation experiment was conducted for optimal wear parameters. The experimental value of COF is 0.38 and predicted value of COF is 0.36 . In case of weight loss, experimental value is $0.00021 \mathrm{gm}$ and predicated value is $0.00020 \mathrm{gm}$. At the optimal condition the error was observed only $5.26 \%$ for COF and $4.76 \%$ for weight loss, 
Table 14. Model summary- COF

$\begin{array}{cccc}\text { S } & \text { R-sq } & \text { R-sq (adj) } & \text { R-sq (pred) } \\ 0.0035355 & 99.98 \% & 99.84 \% & 98.53 \%\end{array}$

Table15. Model summary- Weight loss

\begin{tabular}{cccc}
\hline S & R-sq & R-sq (adj) & R-sq (pred) \\
0.0001096 & $99.97 \%$ & $99.76 \%$ & $97.80 \%$ \\
\hline
\end{tabular}

Table 16. Experimental and Predicated value of COF and weight loss

\begin{tabular}{cccccc}
\hline $\begin{array}{c}\text { Type of } \\
\text { material }\end{array}$ & Load $(\mathrm{P})$ & Velocity $(\mathrm{V})$ & $\begin{array}{c}\text { Track diameter } \\
(\mathrm{TD})\end{array}$ & $\begin{array}{c}\text { Predicted value of } \\
\text { COF }\end{array}$ & $\begin{array}{c}\text { Experimental value of } \\
\text { COF }\end{array}$ \\
$\begin{array}{c}\text { CoCrMo } \\
\text { Type of }\end{array}$ & $5 \mathrm{~N}$ & $0.05 \mathrm{~m} / \mathrm{s}$ & $20 \mathrm{~mm}$ & 0.36 & 0.38 \\
material & Load $(\mathrm{P})$ & Velocity $(\mathrm{V})$ & $\begin{array}{c}\text { Track diameter } \\
(\mathrm{TD})\end{array}$ & $\begin{array}{c}\text { Predicted value of } \\
\text { weight loss in gram }\end{array}$ & $\begin{array}{c}\text { Experimental value of } \\
\text { weight loss in gram }\end{array}$ \\
CoCrMo & $5 \mathrm{~N}$ & $0.05 \mathrm{~m} / \mathrm{s}$ & $30 \mathrm{~mm}$ & 0.00020 & 0.00021 \\
\hline
\end{tabular}

which indicates predicted values is very close to the experimental values and model is significant to predict the COF and weight loss. From the confirmation test it is clear that tribological properties significantly depend upon the type of substrate material used for manufacturing the orthopedic bioimplant product. COF and weight loss model of the wear testing has been significantly improved by the optimal setting of wear parameters. Table 16 shows the experimental and predicated values of $\mathrm{COF}$ and weight loss.

The objective of the optimization is to find the best setting of wear parameters. The desirability of optimization has been calculated as 1 that means all wear parameters are within their working range. Figure 7 shows the optimizing graph that shows optimal value of wear parameters for minimum COF.

Figure 8 shows the optimizing graph that shows optimal value of wear parameters for minimum wear weight loss.

\subsection{3-D Surface plots- COF and weight loss}

In order to investigate the effect of independent parameters on COF and weight loss, three dimensional counter plot is drawn. This plot helps in predication of the COF and weight loss at any region of the experimental domain. This plot is generated based on the developed model equation by holding the one parameter as constant for each counter with respect different substrate materials. Figure 9 shows various 3-D plots for COF for the different substrate materials (applied load $x$ sliding velocity, applied load $x$ Track diameter, Velocity $x$ Track diameter).

From figure 9 it shows that the COF increases with increase in applied normal load and sliding velocity,

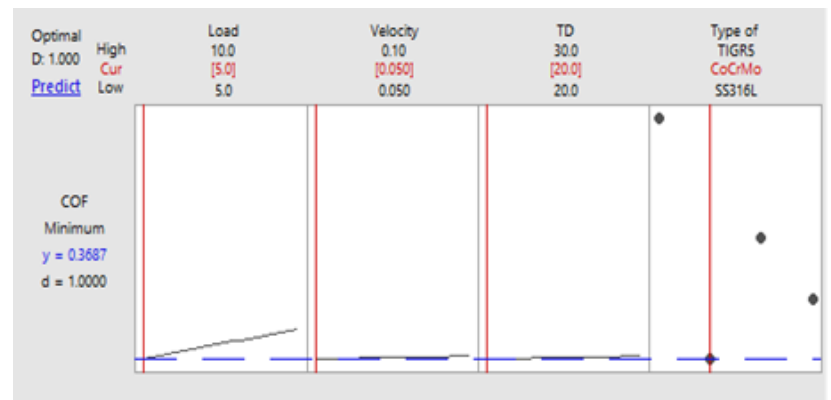

Figure 7. Optimizing graph- COF similarly figure 10 shows various counter plots same as figure 9. From figure 10 it shows that weight loss decreases with decrease in applied normal load and sliding velocity.

\subsection{Microstructure study :}

Figure 11 shows SEM images of different substrates under wet condition. SEM images were taken at MMMF lab, IIT Bombay (Carls Zeiss Microscopy Ltd. Cambridge CB 1 3JS, United Kingdom).SEM images of all substrates for wet test shows wrinkled and rough surfaces. A steel ball of $8 \mathrm{~mm}$ diameter was used as an indentor. This indenter rubbed against the flat surface of substrate materials under different applied normal load and sliding velocity. The formation of wear tracks formed on the flat surface increased with increasing load and velocity by using the rubbing action of the indentor. As increased the load, the material transfer to the contact surface of the indenter observed. The wear between the flat surface of specimen and indentor led to darkening at the contact surface of the indenter by material transfer. The contact surface of the indenters used in the testing of the TIGR2 and TIGR5 material was more markedly darkened as compared to other substrate materials.

The hardness of materials in the ascending order from high to low of CoCrMo, TIGR5, TIGR2, and SS316L [20]. The weight loss in SS 316L is less than TIGR5 and TIGR2 materials. This is because of the formation of oxide islands at some locations as evident from SEM. These oxidized surfaces of SS316L get fragmented or become stable to some extent. The formed fragmented oxide layer or particles sometimes acts as a lubricating agent and thus this oxide layer reduces weight loss. From literature, it was found that in titanium alloy at higher load and sliding

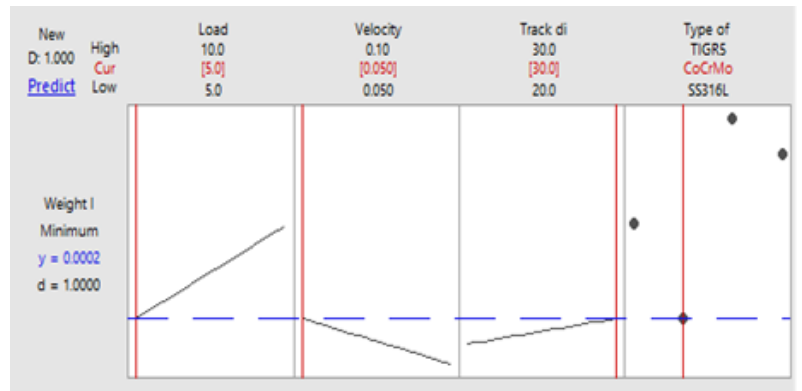

Figure 8. Optimizing graph- Wear weight loss 


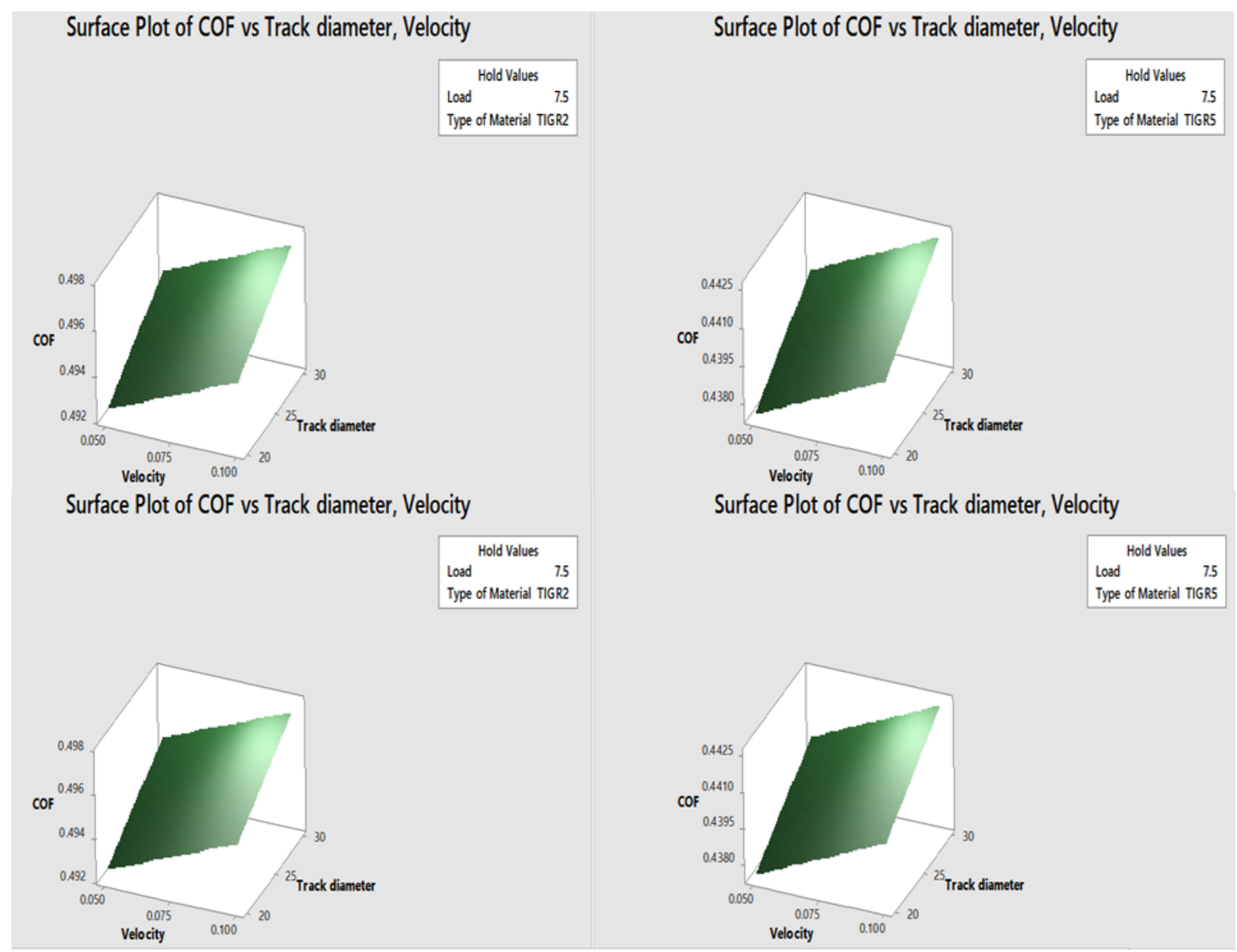

Figure 9. Counter plots - $\mathrm{COF}$

distance there was the formation oxide islands or layers $[24,25,26,27]$. But in this research, we did not see any metal oxide formation for mentioned process parameter except for SS316L material. The dominant wear mechanisms were identified as adhesive for all bioimplant substrate materials under wet conditions.

\section{Conclusion}

1. Pin on disc wear test revealed that CoCrMo material exhibits lower COF compared to other materials such as SS316L, TIGR2, and TIGR5. The CoCrMo material having superior wear resistance and low weight loss properties as compared to other materials by virtue of its hardness and wear resistance property.

2. ANOVA analysis provided the exact amount of percentage (\%) contribution of each factor on $\mathrm{COF}$ and weight loss. From the ANOVA data, it shows that the most significant and influencing input factor affecting the COF and weight loss is the type of material factor.

$\begin{array}{rrr}\text { Input Source / } & \text { \% contribution } & \text { \% contribution } \\ \text { Factor } & \text { for COF } & \text { for weight loss } \\ \text { Load (P) } & 2.77 & 25.00 \\ \text { Velocity (V) } & 0.023 & 5.55 \\ \text { Track diameter } & 0.022 & 2.77 \\ \text { (TD) } & 97.15 & 66.66 \\ \text { Type of material } & 0.022 & 0.00 \\ \text { Error } & 100 & 100 \\ \text { Total } & & \end{array}$

3. Experimental results show the minimum value of $\mathrm{COF}$ is 0.38 and weight loss is $0.00021 \mathrm{gm}$ for CoCrMo substrate material. This minimum value of $\mathrm{COF}$ and weight loss observed at the highest $\mathrm{S} / \mathrm{N}$ ratio $(8.6359 \mathrm{~dB}$ and $73.555 \mathrm{~dB}$ ) which identify the statistically significant parameters that is an applied normal load (P) $5 \mathrm{~N}$ with sliding velocity (V) $0.05 \mathrm{~m} / \mathrm{s}$ for track diameter (TD) 30 $\mathrm{mm}$.

4. In the verification test, the predicted values and experimental values are satisfactorily close to each other. The percentage error was observed only $5.26 \%$ for COF and $4.76 \%$ for wear weight loss which indicates that the developed model can be effectively used for predicting the COF and weight loss of bioimplant substrate materials 


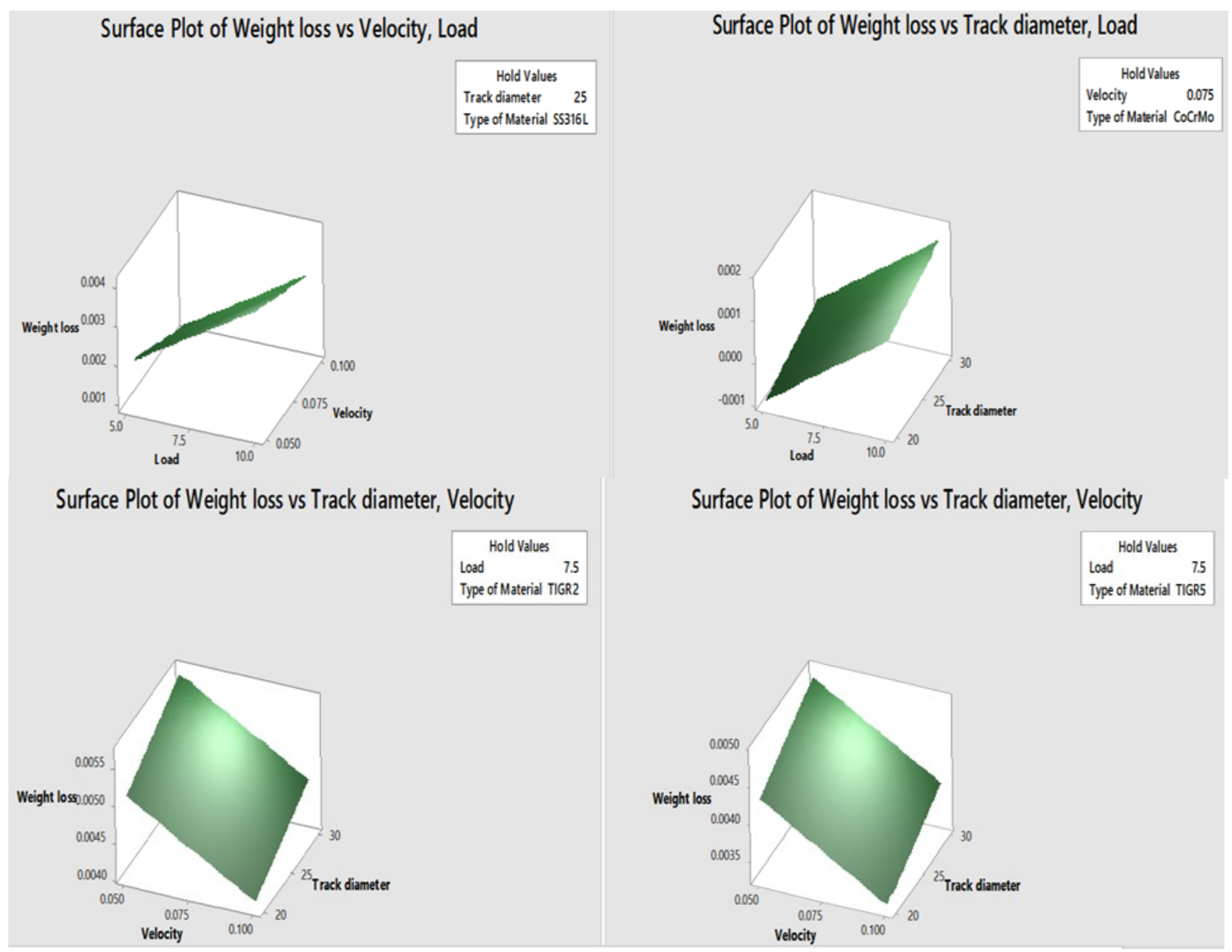

Figure 10. Counter plots - Wear weight loss

with 95\% confidential level. The predicated model will give the optimum results for $\mathrm{COF}$ and weight loss.

5. The dominant wear mechanisms were identified as adhesive for all bioimplant substrate materials under wet conditions. This is evident from SEM.

6. Weight loss values of CoCrMo substrate material observed less compared to TIGR5, TIGR2, and SS316L but considering the strength to weight factor which is important properties in biomedical implant material industry, we suggest the TIGR5 and TIGR2 suitable material for bioimplant material but the comparison between TIGR5 and TIGR2, weight loss of TIGR2 very close to TIGR5 material so as the economic and commercial availability point view, TIGR2 is the best material option for the orthopedic implant material.

7. The measured value of COF and wear weight loss with respect to different substrate materials for the input process parameters are very close to each other which indicates that experiments performed effectively and satisfactorily manner at ambient temperature. This research is congruous with data provided for orthopedic materials by some researchers previously.

8. For the superior performance of bioimplant material, this study demands the necessity of surface modification of various substrates by using different surface coating methods. Also, it is important to study the effect of surface coating and the surface topography generation process. In vitro and In vivo biocompatibility behavior of different coated substrates needs to be investigated.

\section{Acknowledgment}

The authors sincerely thank Plasma Biotal India Pvt. Ltd., Pune, India for providing the testing facility and support. I am equally thankful to the Ministry of Tribal Affairs - Government of India for providing financial support during the research work of my Ph.D. Course. The authors grateful to the General Engineering Department, ICT, Mumbai, India for availing the research support and direction to carried out the present research. 

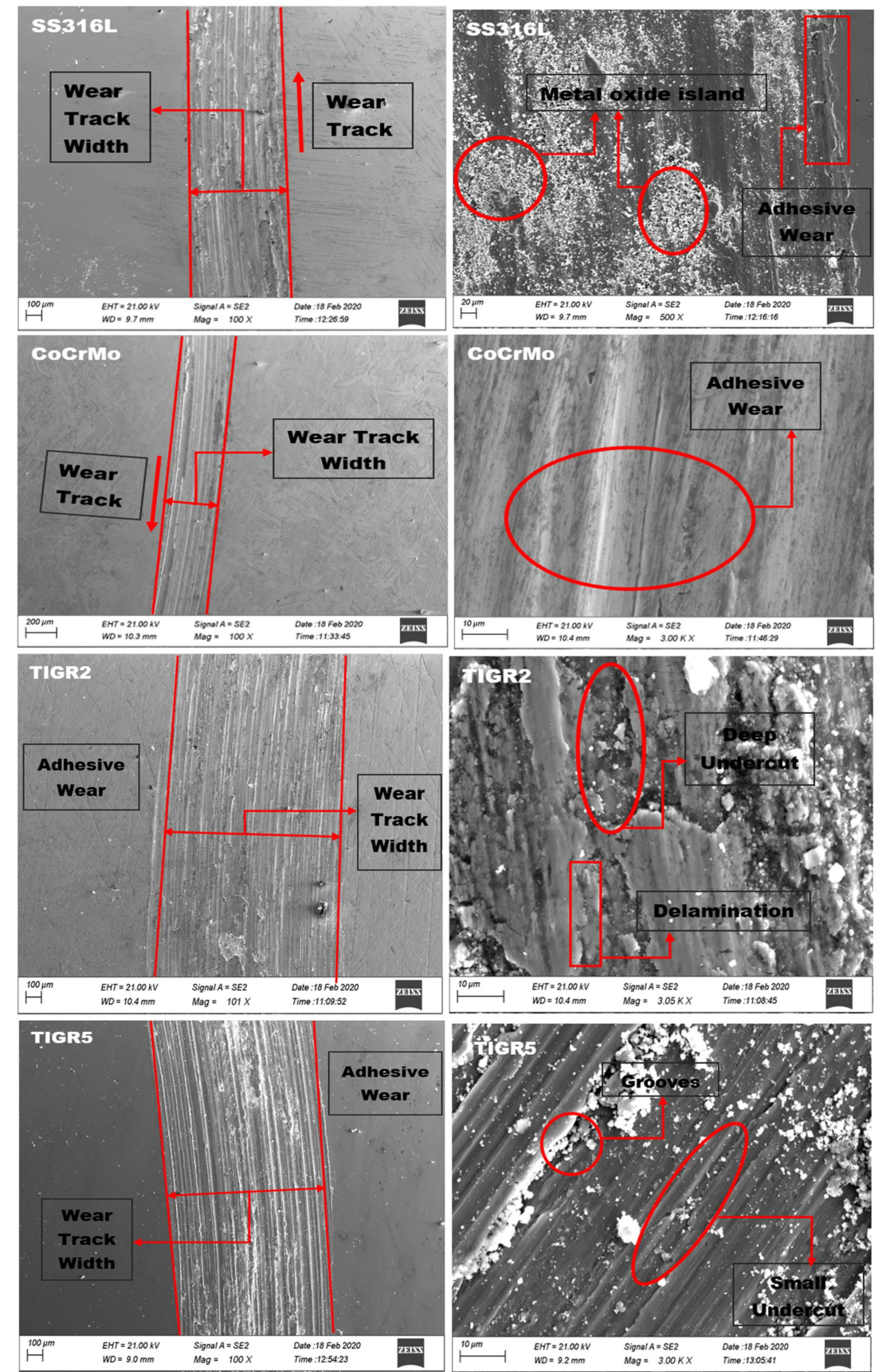

Figure 11. SEM images of different substrates.

\section{Nomenclature}

\begin{tabular}{ll}
\hline ANOVA & Analysis of variance \\
\hline COF & coefficient of friction \\
\hline CoCrMo & Cobalt chromium molybdenum (ASTM F75) \\
\hline OA & Orthogonal array \\
\hline SBF & Simulated body fluid \\
\hline SEM & Scanning Electron Microscope \\
\hline S/N & Signal to noise \\
\hline SS316L & Stainless Steel 316L \\
\hline TIGR5 & Titanium Grade 5 (Ti6Al4V) \\
\hline TIGR2 & Titanium Grade 2 \\
\hline
\end{tabular}

\section{References}

[1] Zivic, F., Babic, M., Grujovic, N., and Mitrovic, S., (2010) "Tribometry of Materials for Bioengineering Applications", Tribology in industry, 32, 5: 25-32.

[2] Hallab, N., Jacobs, J., and Katz, J., (2004) “Orthopedic Applications". Elsevier. San Deigo. U.S.A.

[3] Jones, L. Tsao, A., and Topoleski, L., (2013), "12 Factors contributing to orthopaedic implant wear", Wear of orthopedic implant and artificial joints, 15, 8: 310-350, https:// doi.org/10.1533/9780857096128.1.310

[4] Park, B. and Bronzino, J. (2003) “Biomaterials: Principles and Applications". CRC Press. New York. 
[5] Hin, T. (2004) “Engineering Materials for Biomedical Applications". World Scientific Publishing. London.

[6] Choubey, A., Basu, B., and Balasubramaniam, R., (2004) "Tribological behavior of Ti-based alloys in simulated body fluid solution at fretting contact", Trends Biomater. Artif. Organs, 379, 1-2: 234- 239, https://doi.org/10.1016/j.msea.2004.02.027

[7] Solanke, S., Gaval, V., \& Sanghavi, S. (2021) “In vitro tribological investigation and osseointegration assessment for metallic orthopedic bioimplant materials" In Proceedings of Materials Today Conference, 44 (6), 4173-4178, https:// doi.org/10.1016/j.matpr.2020.10.528

[8] Chandrasekaran, M. (2002) "Materials Degradation and its Control by Surface Engineering". World Scientific Publishing Co. Pte. Limited. London.

[9] Wimmer, M., Fischer, A., Buscher, R., Sprecher C., and Hauert, R. (2010) “Wear mechanisms in metal-onmetal bearings: The importance of tribochemical reaction layers", Journal of Orthopedic Research, 28: 436-444, https:// doi.org/10.1002/jor.21020

[10] Tiainen, T. (2017) “Focus on friction and wear - The 40th anniversary seminar of the Finnish Society for Tribology in Tampere", Tribologia - Finnish Journal of Tribology, 35(3), 16-19. Retrieved from https:/ / journal.fi/tribologia/article/view/68996

[11] Ramadan, N. E., Khaled, M.I., Azza, F. B., and Reham R. B. (2017) "Effect of Heat Treatment Processes on Microstructure and Mechanical Behavior of TC21 Titanium Alloy", Open Journal of Metal 7, 9: 39-57, https://doi.org/10.4236/ojmetal.2017.73004

[12] Patel, B., Favaro, G., Inam, F., Reece, M. J., Angadji, A., Bonfield, W., Huang, J., and Edirisinghe, M. (2012) “Cobalt-based orthopaedic alloys: Relationship between forming route, microstructure and tribological performance" Materials 32, 5:1222-1229, https://doi.org/10.1016/j.msec.2012.03.012

[13] Antony, J. 2008. "Design of experiments". Elsevier Ltd. New York.

[14] Sachin, G., Ankush, M., and Yogesh, B. (2017) "Integrated Taguchi-simulated annealing (SA) approach for analyzing wear behaviour of silicon nitride", Journal of Applied Research and Technology, 15, 6: 624-632, https:// doi.org/10.1016/ j.jart.2017.08.003

[15] Babu, N., Saravanabava, G., Venkatakrishnan, S., Selvavignesh, R., and Sanjeevi, V. (2019) “Optimization of Dry Sliding Wear Parameters of Titanium Alloy using Taguchi Method" International Journal of Innovative Technology and Exploring Engineering, 8, 11: 2278-3075. https:/ / doi.org/ 10.35940/ijitee.K2501.0981119

[16] M. Ipavec, A. Iglic, V. K. Iglic, and K. Srakar (1996), "Stress distribution on the hip joint articular surface during gait", European Journal of Physiology, vol. 431, 275-276, https:/ / doi.org/10.1007/BF02346375

[17] Solanke S.G., Gaval, V., Pratap, A., Pasarkar, M. (2021) "Crystallinity and cell viability in plasma- sprayed hydroxyapatite coatings" Jurnal Tribologi, 30, 61-72, https:/ /jurnaltribologi.mytribos.org/v30/ JT-30-61-72.pdf

[18] L. Neumann, K. G. Freund, and K. H. Sorenson (1994) "Long-term results of Charnley total hip replacement. Review of 92 patients at 15 to 20 years", vol. 76, 245251, https://doi.org/10.1016/0883-5403(94)90041-8

[19] Kokubu, T., Kushitani, H., Sakka, S., Kitsugi, T., and Yamamuro, T. (1990), "Solutions able to reproduce in vivo surface-structure changes in bioactive glassceramic", Material Research, 24: 721-734, https:// doi.org/ 10.1002/jbm.820240607

[20] Solanke, S. G., \& Gaval, V. R. (2020) “Tribological Studies of Different Bioimplant Materials for Orthopaedic Application" ASM Sc. J., 13, https:/ / doi.org/10.32802/asmscj.2020.526

[21] Kamaruddin, S., Zahid, A. K., and Foong, S. H. (2010) "Application of Taguchi Method in the Optimization of Injection Moulding Parameters for Manufacturing Products from Plastic Blend", IACSIT International Journal of Engineering and Technology, 2, 6: 574-580, https:/ / doi.org/10.7763/IJET.2010.V2.184

[22] Yıldırım, C. V., Kıvak, T., Sarıkaya, M., and Erzincanl1, F. (2017) “Determination of MQL Parameters Contributing to Sustainable Machining in the Milling of Nickel-Base Superalloy Waspaloy", Arabian Journal for Science and Engineering, 42, 11: 4667- 4681, https:/ / doi.org/10.1007/s13369-017-2594 $-\mathrm{Z}$

[23] Chatterjee, S., Rudrapati, R., Kumar, P., and Nandi, G. (2018) “Experiments analysis and parametric optimization of cylindrical traverse cut grinding of aluminium bronze", Materials Today: Proceedings, 5, 2: 5272-5280, https:// doi.org/10.1016/ j.matpr.2017.12.110

[24] Chauhan, S. R., and Kali, D. (2013) “Dry Sliding Wear Behaviour of Titanium (Grade 5) Alloy by Using Response Surface Methodology", Advances in Tribology, 13, 1: 1-9, https:/ / doi.org/10.1155/2013/272106

[25] Solanke, S. G., and Gaval, V. R. (2020) “Optimization of wet sliding wear parameters of Titanium grade 2 and grade 5 bioimplant materials for orthopedic application using Taguchi method", Journal of Metals, Materials and Minerals, 30 (3), https:/ / doi.org/ 10.14456/jmmm.2020.44

[26] ATLA, S., \& Kaujala, P. L. (2020). Investigation of graphite effect on the mechanical and tribological properties of Al 7075-SiC-graphite hybrid metal matrix composites. Tribologia - Finnish Journal of Tribology, 37 (1-2), 26-32, https:/ / doi.org/10.30678/ fjt.82667

[27] Andersson, P., Kilpi, L., Holmberg, K., Vaajoki, A., \& Oksanen, V. (1). Static friction measurements on steel against uncoated and coated cast iron. Tribologia Finnish Journal of Tribology, 34 (1-2), 5-36, https:/ / journal.fi/tribologia/article/view/58520 